\title{
ASSESSMENT OF GROUP EFFECTIVENESS: FISH FARMERS GROUP IN THE MINAPOLITAN AREA OF HULU SUNGAI UTARA REGENCY, SOUTH KALIMANTAN, INDONESIA
}

\author{
Sofia Leila Ariyani ${ }^{*}$, Zain Muhammad Adnan \\ Study Program of Fishery Agribusiness, Faculty of Fishery and Marine, \\ University of Lambung Mangkurat, Banjarmasin, Indonesia \\ *E-mail: leila.ariyani@ulm.ac.id
}

\begin{abstract}
Fish farmer groups are forums for farmers to share knowledge, tools, technology and aquaculture innovations with other members. This study aims to analyze the factors that shape the effectiveness of fish farmer groups and assess the level of effectiveness of fish farmer groups in the minapolitan area. The study location was determined to be the minapolitan area of Haur Gading, Hulu Sungai Utara Regency, South Kalimantan. A total of 9 groups of fish farmers who are still active with 54 fish farmers, were used as respondents for this study. Primary data were analyzed using qualitative descriptive analysis. The results show that assessing the three aspects of group characteristic factors in the fish farmer group is high. Meanwhile, five aspects of the working factors of fish farmer groups are still classified as moderate. External factors from the group are aspects of support from formal and informal leaders are high, but from the aspect of physical condition, the group's location is moderate. Then, the level of group effectiveness from the satisfaction aspect of the fish farmer group is high, but from the productivity aspect, it is still moderate. Several things need to be improved, so that fish farmer groups in the Minapolitan area become more effective, namely encouraging the involvement and initiative of members in group activities, improving group facilities, and increasing the productivity of group members.
\end{abstract}

\section{KEY WORDS}

Group, fish farmer, assessment, effectiveness, minapolitan, management.

The territorial waters are one of the natural resources owned by Indonesia, with an area of 5.3 million $\mathrm{km} 2$ or $70 \%$ of the total area of Indonesia. Water resources have long been used by residents, one of which is the fishery business. Fisheries contribute to the country's economic growth, including sources of foreign exchange, supporting the receipt of Original Regional Income (ORI), as well as in the growth of Gross Domestic Product (GDP) (Budiani et al., 2020). The fishery sector's contribution to GDP reaches $19 \%$, and it ranks third highest in GDP in agriculture, forestry, and fisheries.

The development of minapolitan areas in several regions in Indonesia is one of many government policies implemented to optimize the utilization of fishery resources to achieve the welfare of the main actors in the fisheries business (fishermen and fish cultivators). Minapolitan is a regional-based marine and fishery economic development concept with an approach and area management system based on the principles of integration, efficiency and quality, and high acceleration (Minister of Maritime Affairs and Fisheries of the Republic of Indonesia, 2010a). The success of a program based on a regional approach requires management institutions (Yulisti \& Triyanti, 2012). Fish farmer groups are one of the institutions that facilitate joint management among fish farmer groups by requiring social capital (Pertiwi et al., 2018). The existence of farmer groups is a forum for farmers to share knowledge, various tools, technology, or agricultural innovations with other members (DansoAbbeam et al., 2018; Muhdlor et al., 2018). The appearance and participation of farmers in groups aim to achieve social and economic benefits through collective activities (Sheilla, 2018). The group's number of goals is set and planned, especially to improve livelihoods, business activities in rural areas and even become a way to help the poor.

The achievement of group goals can be seen from the group's effectiveness. 
Effectiveness is a form of organizational capacity to obtain the implementation of tasks to achieve targets in a directed manner in carrying out various efforts to achieve goals, as well as the existence of policies as efforts to implement program preparation, also available work facilities and infrastructure, users and ability to complete tasks (Sunarti, 2019). Effectiveness in farmer groups is used to analyze group goals and member goals that have not been achieved so that group activity planning will be moved in a more productive and effective direction (Kusnadi, 2006).

The level of effectiveness of farmer groups is determined by the factors that shape the effectiveness of farmer groups. Factors forming group effectiveness consist of factors within the group and factors outside the group and group work factors (Da Costa et al., 2016). Factors in the group are group leadership, cohesiveness, and the intensity of group meetings. Factors outside the group consist of support from the formal leader and the physical condition of the group location. At the same time, the group work factor consists of providing information, the function of satisfying, the function of organizing coordination, the function of generating initiative, the function of inviting participation, and the function of explaining.

This study aims to analyze the factors that shape the effectiveness of fish farmer groups and assess the effectiveness of farmer groups in aquaculture in the minapolitan area. The availability of up-to-date and accurate information about the effectiveness of fish farmer groups is expected to be used as input in planning extension programs and fostering fish farmer groups in freshwater wetlands.

\section{METHODS OF RESEARCH}

The research location was determined intentionally, namely the Haur Gading minapolitan area, Hulu Sungai Utara Regency as a center for production activities and production services (seed supply), and other production services (HSU Pemerintah Daerah, 2014; Minister of Maritime Affairs and Fisheries of the Republic of Indonesia, 2010b). The priority of activities in this main zone is as a center for catfish aquaculture and production. The location of the aquaculture area is presented in Figure 1. Primary data collection was carried out in June - September 2020.

A research population is a group of fish cultivators who are still active as many as nine fish farmers with 54 fish farmers. Primary data collection using interview techniques with the help of closed questionnaires which is a modification of the group effectiveness assessment table from Astuti (2010) (Appendix 1) and Focus Group Discussion approach.

Factors forming the effectiveness of fish farmer groups consist of: (1) group characteristics, including leadership, cohesiveness, and intensity of group meetings; (2) group work factors include the function of organizing coordination, the function of generating initiative, the function of satisfying members, the function of inviting participation, and the function of explaining; and (3) factors outside the group include support from formal and nonformal leaders, as well as the physical condition of the group location. The primary data that has been collected was analyzed using qualitative descriptive analysis. Qualitative data is given an assessment that has been compiled based on the Likert scale (Siegel, 2011).

Table 1 - Score on the Questions of the Variables Factors Forming Group Effectiveness

\begin{tabular}{|c|c|c|c|c|}
\hline Variable & Category & Score & Number of Respondent (org) & Percentage (\%) \\
\hline & High & 3 & $\mathrm{nh}$ & (score $\times \mathrm{nh}) / \mathrm{N} \times 100 \%$ \\
\hline Factors Forming Group Effectiveness & Moderate & 2 & $\mathrm{~nm}$ & $($ score $\times \mathrm{nm}) / \mathrm{N} \times 100 \%$ \\
\hline & Low & 1 & $\mathrm{nl}$ & (score $\times \mathrm{nl}$ )/N x 100\% \\
\hline
\end{tabular}

Adverb: $S H=$ highest score; $S M=$ moderate score; $S L=$ lower score; $N=$ total respondent.

Determination of the value of each factor is done by assigning a score to each answer with a value range of 1-3, where a value of 1 is given to the option that indicates low; a value of 2 is assigned to the option indicating moderate, and a value of 3 is assigned to the option indicating high. The determination of this score is following the rules of the ordinal Likert 
scale, namely the existence of positive, neutral, and negative values. The results of the recapitulation of answers will be processed in tabulated form as in Table 1.

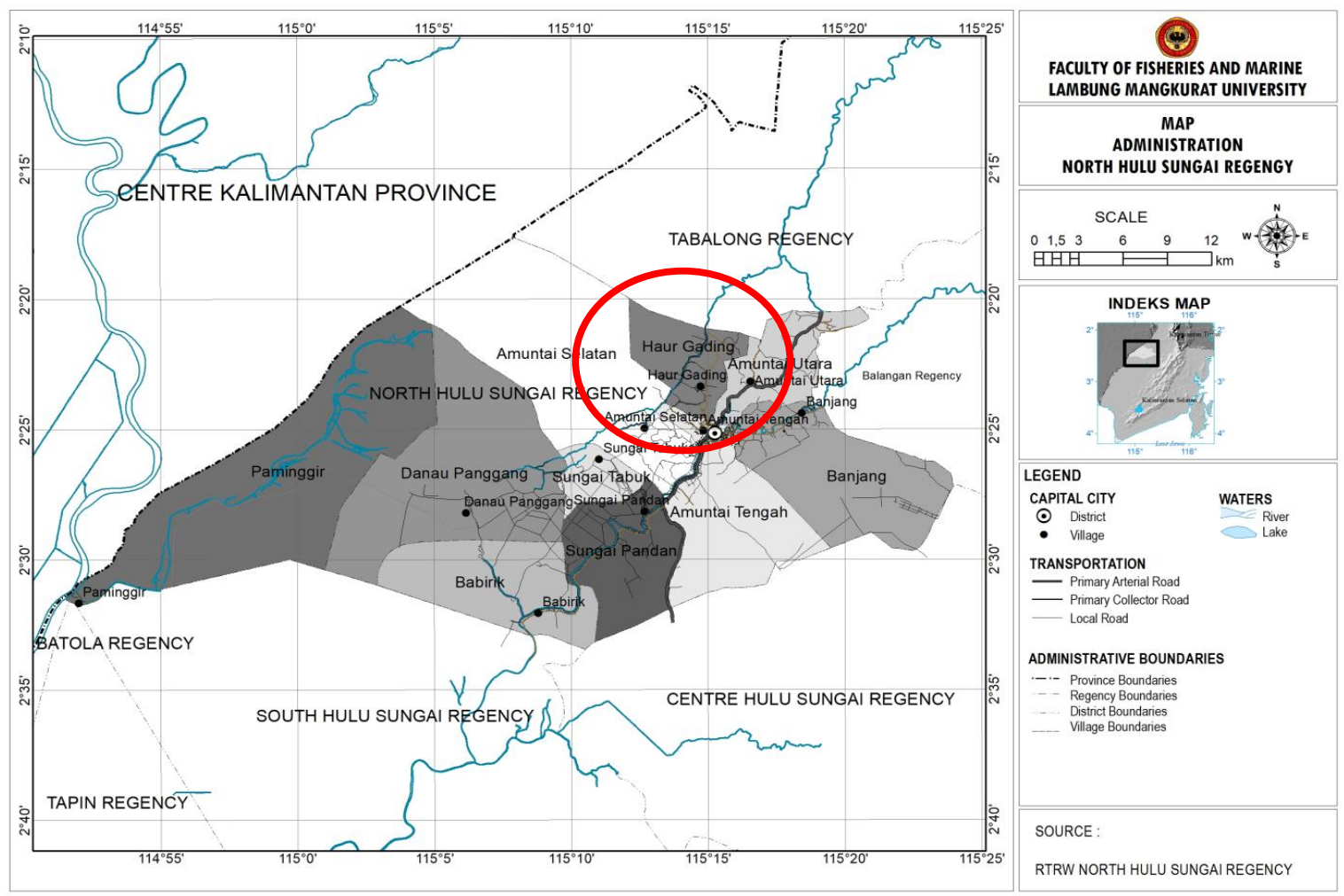

Figure 1 - Location of the Fish Farmer Group in Minapolitan Hulu Sungai Utara Regency, Indonesia

\section{RESULTS OF STUDY}

Factors forming group effectiveness consists of characteristic group factors, group work factors, and factors outside the group. The group characteristic factors are related to the social conditions that make up the situation in the group, accompanied by the background of how these conditions can be formed. The characteristic group factor consists of several components: leadership, cohesiveness, and the intensity of group meetings.

The group characteristic factor analysis results show that all indicators of group characteristics in the fish farmer group are high (Figure 2). Around $87.5 \%$ of respondents stated that the leadership characteristics in the fish farmer group were in the high category. The group cohesiveness factor as measured by interpersonal relationships between groups and cooperation between members showed that $75 \%$ of the fish farmer group members stated that the fish farmer group cohesiveness was high. In comparison, the remaining $25 \%$ stated the fish farmer group cohesiveness was classified as moderate. Likewise, the intensity factor of meeting fish farmer groups in the minapolitan area, according to $77.08 \%$ of respondents, is high. Group work factors are activities carried out by groups so that group goals can be achieved. The group work factor consists of five main group functions: the function of coordinating, the function of generating initiative, the function of satisfying members, the function of inviting participation, and explaining.

Based on the analysis of the work factor indicators of the fish farmer group, it shows that the function of generating initiative is still relatively low compared to the response to other functions (Figure 3). It is possible that some group members can still not propose initiatives to develop the group and its business. Meanwhile, the function of satisfying members of the fish farmer group, according to $72.92 \%$ of respondents, is considered high. To coordinate fish farmer groups in Haur Gading district, it is known that $70.83 \%$ of 
respondents stated that this function was classified as high. The group can gather and involve its members, although sometimes some members cannot participate because they have to do other business activities.

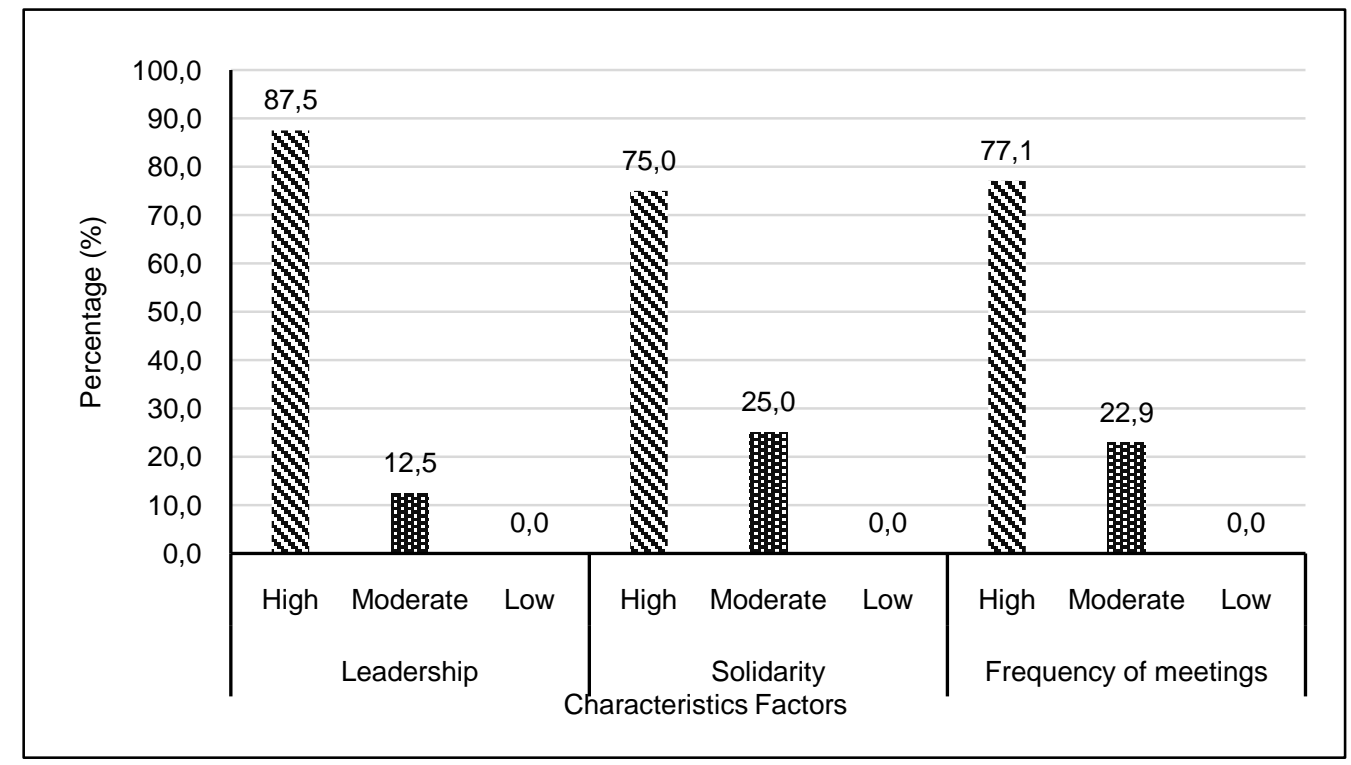

Figure 2 - Characteristics Factors of Fish Farmer Group

The function of producing fish farmer group initiatives in Haur Gading district is high, state by $60.42 \%$ of respondents. The function of inviting participation in fish farmers' groups, about $58.33 \%$ of respondents, stated that inviting participation in fish farmer groups was quite high. The function of explaining in the fish farmer group is that $75 \%$ of the members state that they are in the high category. A social learning process and learning through instructors/extensions help farmer groups improve their farming experience.

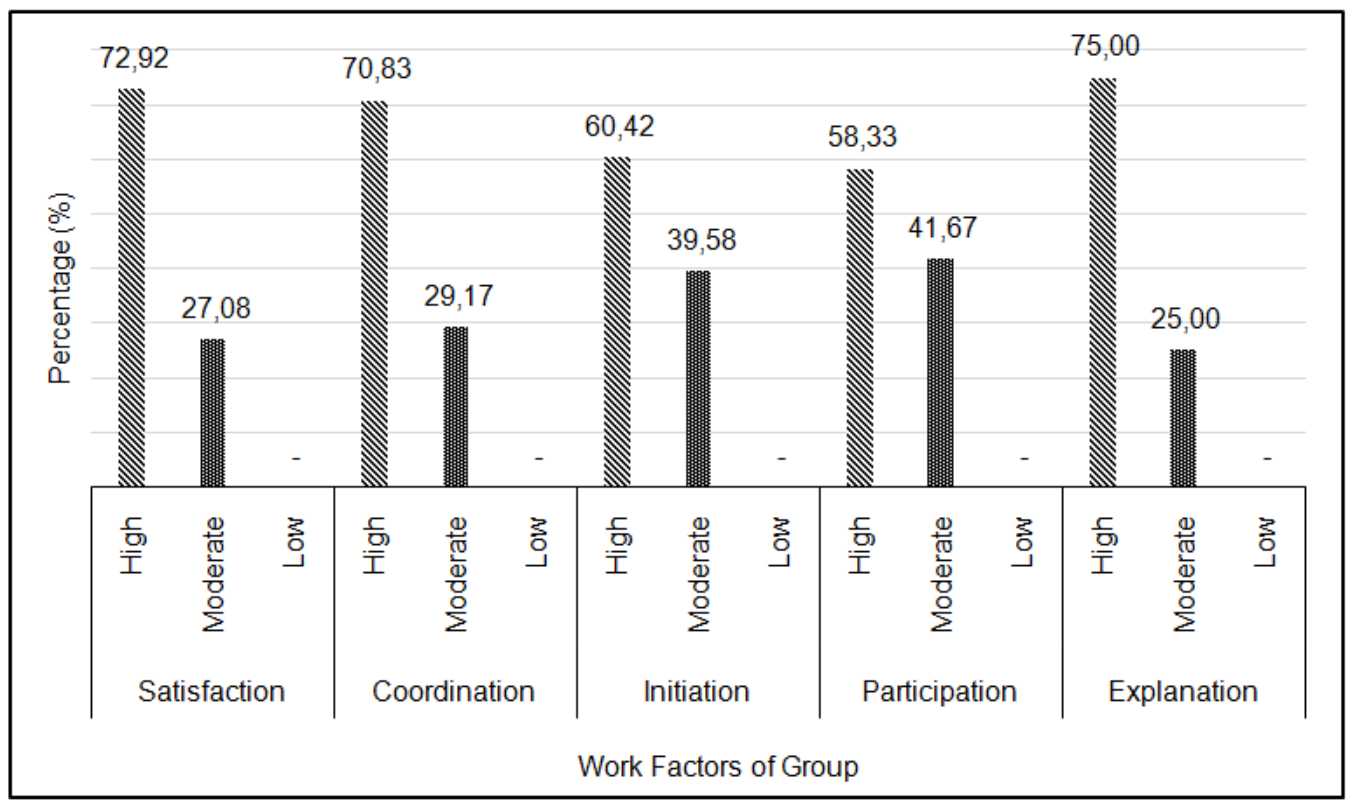

Figure 3 - Work Factors of Fish Farmer Group

External factors consist of support from formal and non-formal leaders and the physical condition of the group location. The results of data analysis of all external factor indicators show that the physical condition of the group location is in the lowest category (Figure 4). Around $93.75 \%$ of respondents stated that they support formal and non-formal leaders in the 
high category. Formal and non-formal leaders provide support to the group in the form of moral support, such as giving approval for establishing a fish farmer group or attending various events in the group. The physical condition of the group location is included in the moderate category based on statements from 24 respondents or $50 \%$. Access to group locations is very easy for members to reach. However, the group still does not have a permanent meeting place or adequate infrastructure. Until now, most of the groups held meetings in one of the fish farmer group administrator or head houses.

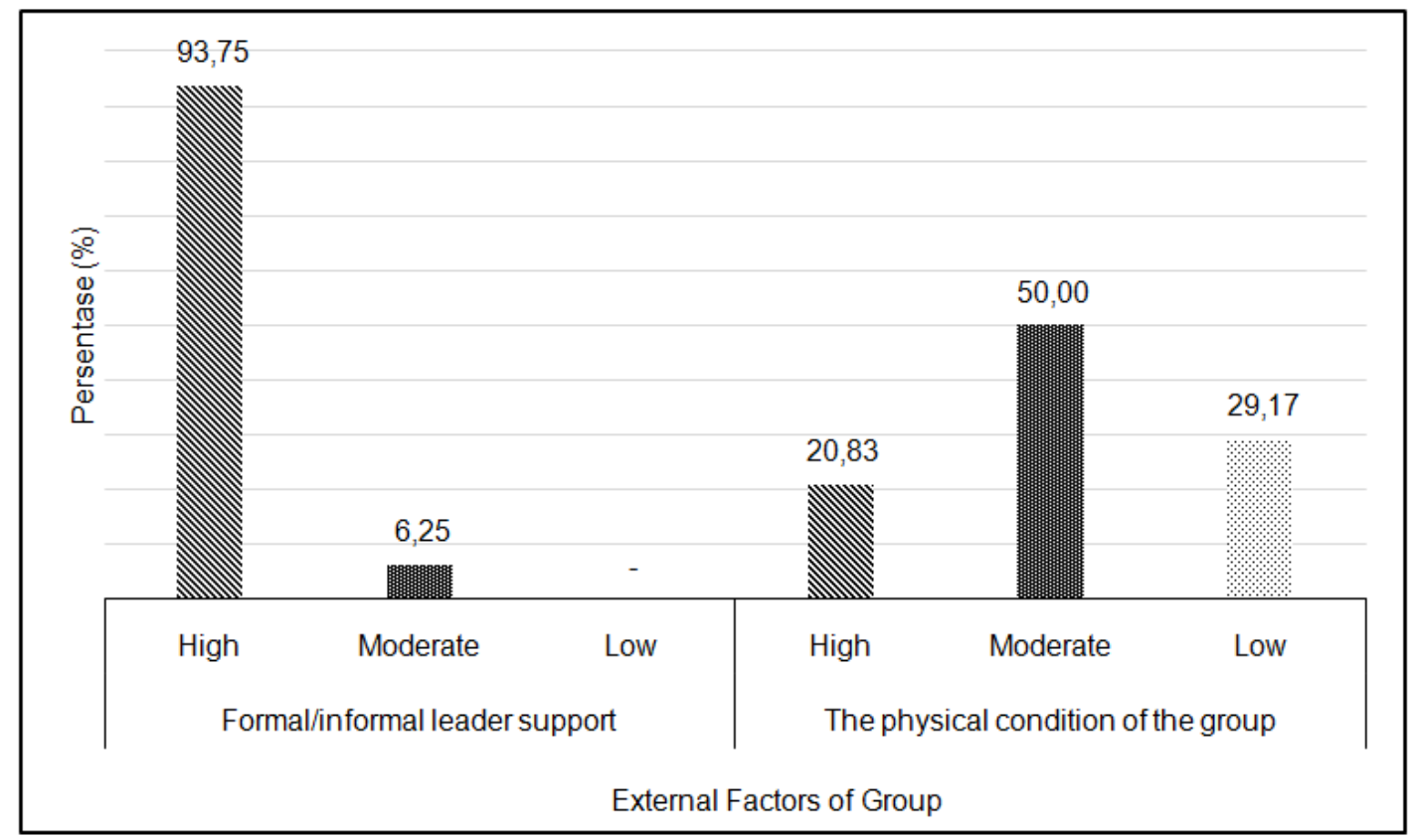

Figure 4 - External Factors of Fish Farmer Group

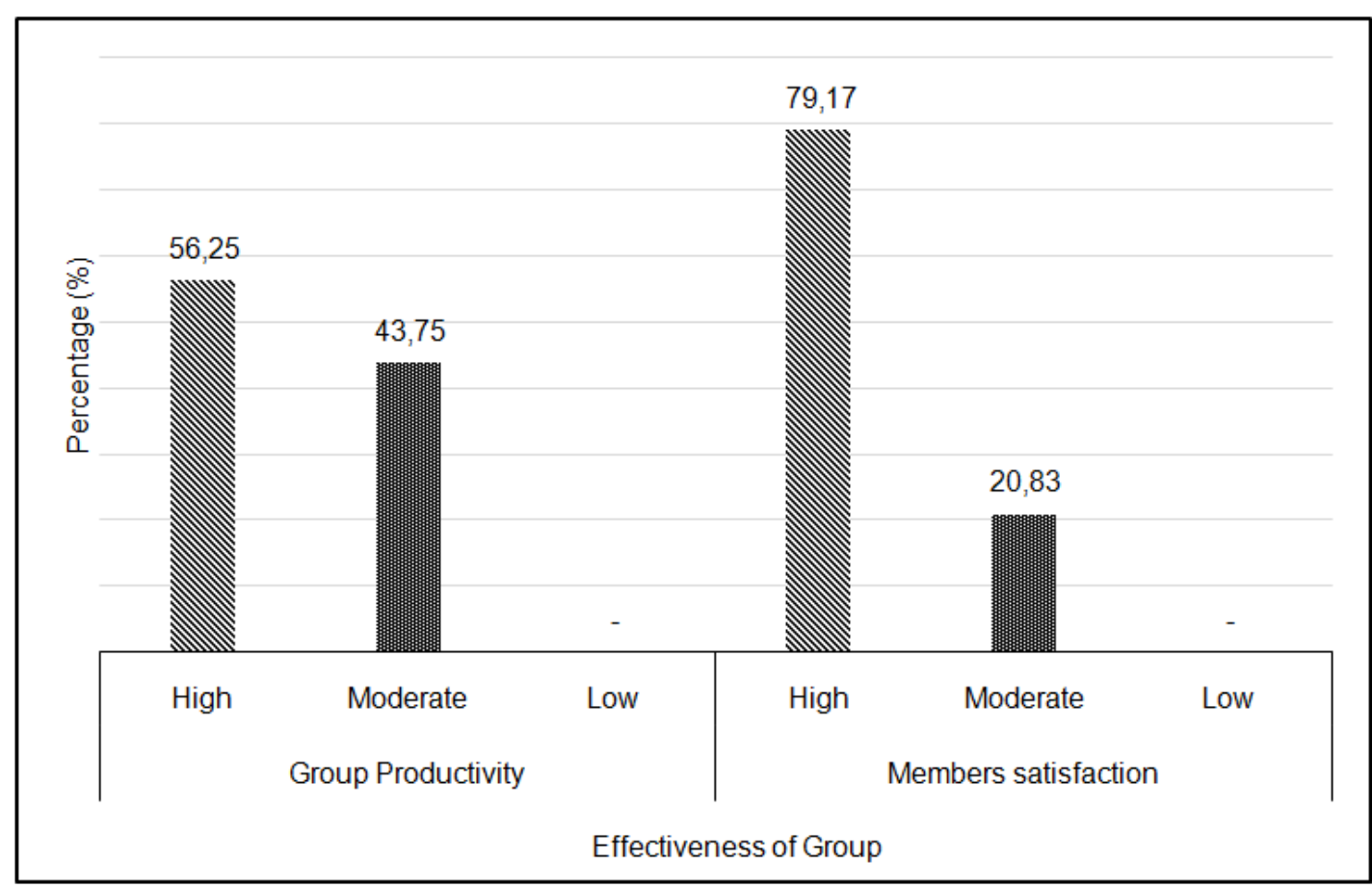

Figure 5 - Effectiveness of Fish Farmer Group

Group effectiveness is the success of a group in achieving a goal characterized by a change in conditions or conditions that satisfy its members. The effectiveness of the group 
can be seen through two things, namely the productivity and satisfaction of its members. The results of data analysis showed that group productivity ranged from moderate $(43.75 \%)$ to high $(56.25 \%)$, and the satisfaction of members of the fish farmer group was high $(79.17 \%)$ (Figure 5).

\section{DISCUSSION OF RESULTS}

The existence of a fish farmer group leader in the Haur Gading minapolitan area is recognized and respected by the members, the leader can coordinate the group and control the members, and there is good communication between the leader and its members. However, there is still leading in some groups that are still classified as lower middle class mainly due to insufficient knowledge of leadership in management and communication. Leadership is one of the important factors to realize the effectiveness of farmer groups. The role of the leader is essential to find alternative problem solving, guarantee tasks in a group, and a high orientation to the task will increase the satisfaction of group members, as well as the leader's belief in group management so that it has an impact on increasing group productivity (Achdiyat, 2018). Group management is related to the leader's ability to manage members, while communication knowledge is related to self-confidence. Self-confidence is one of many factors that affect the effectiveness of communication. A leader has an important role that should be able to provide motivation, direction, supervision, and good communication on the organisation's performance (Fazrien, 2014; Mubarok \& Priatna, 2019) as with parties outside the group. In addition, each leader has his leadership style that will determine his effectiveness in making group decisions. In group decision making, the central role of the group leader is indispensable. The group leader must be wise in making decisions and involving all those in the group. The effectiveness of interpersonal communication of the farmer group leader can be seen from the attitude of the group leader, such as openness, empathy, support, positive attitude and equality. Effective interpersonal communication of group leaders makes leaders in farmer groups maintained (Prasetyo et al., 2017).

Meanwhile, the cohesiveness factor in the group of fish farmers in the study location is quite high because of the group's ability to unite, cooperate, and believe in the group. Meetings of fish farmer groups that are quite intensive in 6 months, i.e. on average more than 3 times, provide greater opportunities for members to interact and exchange information in changing business activities for the better. The suitability of the material and the time of the meeting of the fish farmer group are always adjusted to the needs and time available from the group members. Cohesiveness in the group arises because of the attitude of each group member who is mutually interested and united in cooperation to achieve group goals. The condition of group characteristic factors in fish farmer groups in the Haur Gading minapolitan area, which is quite high, needs to be maintained or further improved by involving all group members more in the preparation of group activity planning and joint evaluation the support and assistance of fisheries instructors. Social cohesiveness in farmer groups can be realized through optimal interaction, communication, cooperation, mutually beneficial cooperation, mutual assistance, and tolerance. Social interaction can be realized by establishing a social process for mutually beneficial cooperation, mutual assistance, and community service associations. Social interactions that occur can be in the form of a socialization process that involves either (a) a person individually, (b) between individuals and groups, (c) between groups and communities, and (d) between individuals, groups, communities and the outside world (Latang et al., 2020).

Other factors forming the effectiveness of fish farmer groups are group work factors, namely the function of satisfying group members, organizing coordination, the function of initiative, the function of participating, and the function of explaining. The function of satisfying the needs of group members includes a sense of security and comfort, such as the availability of business capital, work insurance, facilities and infrastructure, and the availability of information that can support the business. Promoters of farmer groups must produce direct guarantees of the efficacy of productivity expansion strategies to improve farmers' welfare. Failure to intervene will lead to negative perceptions of farmers on 
disseminating agricultural information with a group approach. Negative perceptions of strategic groups will discourage many farmers from joining as members and lead to a decrease in membership (Mwaura, 2014).

Meanwhile, the function of organizing coordination is measured by how many groups can gather and involve all members in each group activity. This allows most groups to be quite capable of facilitating the fulfilment of the needs of their members. For example, the aid program for a fish farmer group is almost evenly distributed to all members because the information on the proposal has been obtained completely, and several group members have met all the requirements for obtaining a grant. However, some groups have not been able to fulfill some of the needs of their members. For example, business capital loan assistance, infrastructure assistance from the local Fisheries Service and group assistance in the form of lending services for aquaculture infrastructure for its members.

The function of generating group initiatives is to give the board and members the right to provide initiatives, although not all initiatives can be realized. Several initiatives have been realized by fish farmer groups in the study locations because the management has sufficient knowledge and experience in organizing, for example, in group administration activities, preparing proposals for submitting capital assistance, etc. For the group's function in inviting members to participate, some groups of fish farmers are quite capable of involving administrators and most members in various fish farming business activities. However, some things do not allow other members to be further involved in coordinating in each activity because the group activity schedule is at the same time as its business activities. Participation in farmer groups is concerned with increasing crop yields and technical efficiency relative to the production and market of products produced by individual farmers (Abdul-Rahaman \& Abdulai, 2018). However, if only membership in the group is not sufficient for the expansion of sustainable development, the group must have the capacity to meet their goals and the services required of members (Abaru et al., 2006). For a group to be influential, farmers need good organisers (Bosc et al., 2001). Groups must have the capacity to deliver relevant services by allowing smallholders to actively participate in collective action at the lowest level (Mukindia, 2012).

Group productivity can be seen from the extent to which the group can fulfil the production facilities of group members within the last year and the achievement of the results obtained in each group activity. In the fish farmer group, the primary need to support aquaculture productivity is the supply of feed, both in terms of product volume and prices that are still efficient for fish farmers. Groups of fish farmers obtain assistance for production facilities through an assistance program from the local Fisheries Service and a reduction in the payment of feed purchases from feed suppliers, namely the cost of feed can be paid by farmers after harvest. However, some farmer groups still experience obstacles in getting the assistance due to limited knowledge and ability to fulfill the requirements for proposing assistance. Therefore, optimizing the role of extension workers as a liaison between policymakers and fisheries business actors as a policy implication is needed. One of the factors that encourage farmers to participate in extension programs is access to agricultural credit. Extension programs allow farmer groups to get more information that is expected to help maximize their yields to pay credit on time (Danso-Abbeam et al., 2018).

Members' satisfaction with the success of participating in the planning and implementation of activities is quite satisfactory. However, some members of the fish farmer group feel that the group's existence has not had a significant impact on their business results. This is closely related to the clarity of the objectives of establishing a fishery business group. In general, the purpose of forming a group is only to fulfill administrative requirements to obtain assistance with fishery facilities needed by members. The lack of clarity of objectives affects the preparation of activity plans and their implementation by less focused groups. Almost all groups do not have a real work program. Members have the freedom to participate in the preparation and implementation of group activity plans. However, the lack of clarity of purpose makes members not enthusiastic about taking an active role in group activities, so the activity of group activities is still very dependent on the management (leader, secretary and finance manager). Therefore, many intervention programs in the agricultural 
sector should focus more attention on strengthening and expanding farmer cooperation for better diffusion (Hunter, 2007; Paltasingh \& Goyari, 2018) and intensive use of innovation and better social capital linkages with extension agents, banks, markets and agricultural value chains (Kolade \& Harpham, 2014). In addition, there is a need for an in-depth understanding of the institutions that facilitate and maintain the strength of linkages with agricultural innovation systems and the complexities associated with promoting the transformation of agricultural innovations (Eidt et al., 2020).

\section{CONCLUSION}

The group characteristics factor in the fish cultivator group in the Haur Gading minapolitan area is relatively high, consisting of leadership aspects (87.5\%), aspects of cohesiveness (75\%), and aspects of meeting intensity (77.08\%). Meanwhile, the group work factor is classified as moderate, both from the function of satisfying members $(72.92 \%)$, the function of organizing coordination (70.83\%), and the function of explaining (75\%); however, the function of generating initiative and the function of inviting participants to participate is still relatively low with response values of $60.42 \%$ and $58.33 \%$, respectively. External factors of the group in support from formal leaders or informal leaders are high (93.75\%), but from the aspect of the physical condition of the group's location, it is in the moderate category $(50 \%)$.

The level of group effectiveness in the fish cultivator group is high from the aspect of group member satisfaction $(79.17 \%)$, but it is still classified as moderate (56.26\%).

\section{REFERENCES}

1. Abaru, M. B., Nyakuni, A., \& Shone, G. (2006). Strengthening farmers' organizations: The experiences of RELMA and ULAMP. 40.

2. Abdul-Rahaman, A., \& Abdulai, A. (2018). Do farmer groups impact on farm yield and efficiency of smallholder farmers? Evidence from rice farmers in northern Ghana. Food Policy, 81. https://doi.org/10.1016/j.foodpol.2018.10.007

3. Achdiyat, D. G. (2018). Relationship between Leadership of the Board with the Effectiveness of Farmers Group. International Journal of Academic Research in Business and Social Sciences, 8(7), 573-582. https://doi.org/10.6007/ijarbss/v8-i7/4400

4. Bosc, P. M., Eychenne, D., Hussein, K., Losch, B., Mercoiret, M. R., Rondot, P., \& Macintosh-Walker, S. (2001). Reaching the rural poor: The Role of Rural Producers Organisations (RPOs) in the World Bank Rural Development Strategy. April.

5. Budiani, S. R., Sari, P. K., Thifaltanti, M. H., Narulita, R. L., Latifah, R., Kusuma, P. B., Isnastuti, N. L., Triawan, R. A., \& Dwiputra, D. S. (2020). Analysis of minapolitan impact on the commuinity welfare in Muncar Subdistrict Banyuwangi Regency (Case Study: Tembokrejo and Kedungrejo villages). Jurnal Sosial Ekonomi Kelautan Dan Perikanan, 15(1), 47-56. https://doi.org/10.15578/jsekp.v15i1.7562

6. Da Costa, A. C., Falo, M., \& Nubatonis, A. (2016). Efektivitas Kelompok Wanita Tani Lestari di Desa Subun Tua'lele Kecamatan Insana Barat Kabupaten Timor Tengah Utara. Agrimor, 1(02), 24-26. https://doi.org/10.32938/ag.v1i02.101

7. Danso-Abbeam, G., Ehiakpor, D. S., \& Aidoo, R. (2018). Agricultural extension and its effects on farm productivity and income: Insight from Northern Ghana. Agriculture and Food Security, 7(1), 1-11. https://doi.org/10.1186/s40066-018-0225-x

8. Eidt, C. M., Pant, L. P., \& Hickey, G. M. (2020). Platform, participation, and power: How dominant and minority stakeholders shape agricultural innovation. Sustainability (Switzerland), 12(2). https://doi.org/10.3390/su12020461

9. Fazrien, A. (2014). Peran pemimpin dalam pencapaian kinerja pegawai (Studi pada Badan Kepegawaian Daerah Kota Malang). Jurnal Administrasi Publik Mahasiswa Universitas Brawijaya, 2(4), 603-607.

10. HSU Pemerintah Daerah. (2014). Peraturan Bupati Hulu Sungai Utara No.20 Tahun 2014 tentang Penetapan Kawasan Strategis Cepat Tumbuh di Kabupaten Hulu Sungai Utara (pp. 1-8). Pemerintah Kabupaten Hulu Sungai Utara. 
11. Hunter, D. (2007). Improving production and accessibility of agricultural information through capacity-building, networking and partnerships in the South Pacific. International Journal of Education and Development Using Information and Communication Technology, 3(3), 132-135.

12. Kolade, O., \& Harpham, T. (2014). Impact of cooperative membership on farmers' uptake of technological innovations in Southwest Nigeria. Development Studies Research, 1(1), 340-353. https://doi.org/10.1080/21665095.2014.978981

13. Kusnadi, D. (2006). Kepemimpinan Kontaktani Dalam Meningkatkan Efektivitas Kelompok Tani (Kasus pada Kelompoktani di Desa Putat Nutug, Kecamatan Ciseeng, Kabupaten Bogor, Jawa Barat). Jurnal Penyuluhan Pertanian, 1(1), 48-60.

14. Latang, Suardi, \& Nasrah. (2020). Social cohesion of farmer groups in Soppeng Regency. Proceedings of the International Conference on Science and Advanced Technology (ICSAT), 709-719. https://ojs.unm.ac.id/icsat/article/view/17744

15. Minister of Maritime Affairs and Fisheries of the Republic of Indonesia. (2010a). a Peraturan Menteri Kelautan dan Perikanan RI No.Per.12/MEN/2010. In Kementerian Kelautan dan Perikanan RI. Kementerian Kelautan dan Perikanan RI. http://jdih.kkp.go.id/peraturan/per-12-men-2010.pdf

16. Minister of Maritime Affairs and Fisheries of the Republic of Indonesia. (2010b). b Keputusan Menteri Kelautan dan Perikanan Republik Indonesia Nomor KEP.32/MEN/2010 tentang Penetapan Kawasan Minapolitan (p. 9 p.). Kementerian Kelautan dan Perikanan RI.

17. Mubarok, M. R., \& Priatna, W. B. (2019). Hubungan gaya kepemimpinan kontak tani terhadap persepsi kinerja kelompok tani ikan lele di Desa Babakan, Ciseeng, Kabupaten Bogor. Jurnal Ekonomi Dan Manajemen, 53-64.

18. Muhdlor, Eddy, \& Satmoko. (2018). Hubungan Kepemimpinan Ketua Dengan Efektivitas Kelompok Tani Di Kecamatan Singorojo Kabupaten Kendal. Jurnal Sungkai, 6(1), 31-49. https://e-journal.upp.ac.id/index.php/sungkai/article/view/1522

19. Mukindia, B. (2012). Influence of collective action on market access among small holder banana farmers in Imenti South District,Kenya. 1(2), 99-110.

20. Mwaura, F. (2014). Effect of farmer group membership on agricultural technology adoption and crop productivity in Uganda. 22, 917-927.

21. Paltasingh, K. R., \& Goyari, P. (2018). Impact of farmer education on farm productivity under varying technologies: case of paddy growers in India. Agricultural and Food Economics, 6(1). https://doi.org/10.1186/s40100-018-0101-9

22. Pertiwi, Y., Rustiadi, E., \& Lubis, D. P. (2018). The role of fish farmers group in the development of minapolitan area in Pasekan District of Indramayu Regency. Jurnal Penyuluhan, 14(2), 222-233.

23. Prasetyo, A., Safitri, R., \& Hidayat, K. (2017). Effectiveness of interpersonal communication of head of farmer group to maintaining existence Sidodadi farmer group. Habitat, 28(3), 99-105. https://doi.org/10.21776/ub.habitat.2017.028.3.14

24. Sheilla, J. T. (2018). What factors influence performance of farmer groups? A review of literature on parameters that measure group performance. African Journal of Agricultural Research, 13(23), 1163-1169. https://doi.org/10.5897/ajar2017.12205

25. Siegel, S. (2011). Statistik Non Parametrik untuk Ilmu-ilmu Sosial (Z. Suyuti \& L. Simatupang (eds.); 3rd ed.). https://www.goodreads.com/book/show/20556797-statistik-non-parametrik-untuk-ilmuilmu-sosial

26. Sunarti, N. (2019). Efektivitas Pemberdayaan Dalam Pengembangan Kelompok Tani di Pedesaan. Jurnal Moderat, 5(2), 80-100.

27. Yulisti, M., \& Triyanti, R. (2012). Peran Kelembagaan Dalam Mendukung Program Minapolitan Budidaya Di Kabupaten Sleman, D.I. Yogyakarta. Buletin Ilmiah Marina $\begin{array}{llll}\text { Sosial Ekonomi Kelautan Dan Perikanan, } & \text { 7(1), }\end{array}$ https://doi.org/10.15578/marina.v7i1.4595 


\section{APPENDIX - Criteria for the assessment of the effectiveness variable of fish farmer groups}

\begin{tabular}{|c|c|c|c|c|c|}
\hline \multirow{2}{*}{ No. } & \multirow{2}{*}{$\begin{array}{l}\text { Variable } \\
\text { Characteristic factors of } \\
\text { group }\end{array}$} & \multicolumn{2}{|c|}{ Indicator } & \multirow[t]{2}{*}{ Score } & \multirow[t]{2}{*}{ Parameter } \\
\hline & & & & & \\
\hline & a. Leadership & 1) & The existence of a leader in the group & 3 & $\begin{array}{l}\text { High: recognized, respected and easily } \\
\text { contacted by members }\end{array}$ \\
\hline & & & & 2 & Moderate: recognized but not respected \\
\hline & & & & 1 & Low: just a formality \\
\hline & & 2) & The role of the leader in the group & 3 & $\begin{array}{l}\text { High: leader have the ability to control } \\
\text { members }\end{array}$ \\
\hline & & & & 2 & Moderate: the leader only has a position \\
\hline & & & & 1 & $\begin{array}{l}\text { Low: leader do not have the ability to } \\
\text { control members }\end{array}$ \\
\hline & & 3) & Leadership style & 3 & $\begin{array}{l}\text { High: democratic, how the leader invites } \\
\text { members to decide the goals of the group }\end{array}$ \\
\hline & & & & 2 & $\begin{array}{l}\text { Moderate: laissez faire, if the leader } \\
\text { submits all goals/activities to members }\end{array}$ \\
\hline & & & & 1 & $\begin{array}{l}\text { Low: authoritarian, how does the leader } \\
\text { decide for himself all the goals of the } \\
\text { group }\end{array}$ \\
\hline & b. Cohesiveness & 1) & Interpersonal relations between members & 3 & $\begin{array}{l}\text { High: relationships between members are } \\
\text { established, both inside and outside group } \\
\text { activities }\end{array}$ \\
\hline & & & & 2 & $\begin{array}{l}\text { Moderate: relationships between } \\
\text { members are established only in group } \\
\text { activities }\end{array}$ \\
\hline & & & & 1 & $\begin{array}{l}\text { Low: there is no relationship between } \\
\text { members, both inside and outside group } \\
\text { activities }\end{array}$ \\
\hline & & 2) & Role of members in group activities & 3 & $\begin{array}{l}\text { High: very instrumental, if members } \\
\text { always play a role in every group activity }\end{array}$ \\
\hline & & & & 2 & $\begin{array}{l}\text { Moderate: less role, if members rarely } \\
\text { participate in group activities kegiatan }\end{array}$ \\
\hline & & & & 1 & $\begin{array}{l}\text { Low: does not play a role, if members do } \\
\text { not play a role in every group activity }\end{array}$ \\
\hline & & 3) & Cooperation & 3 & $\begin{array}{l}\text { High: if there is always cooperation } \\
\text { between members based on group goals }\end{array}$ \\
\hline & & & & 2 & $\begin{array}{l}\text { Moderate: if sometimes, there is } \\
\text { cooperation between members based on } \\
\text { group goals }\end{array}$ \\
\hline & & & & 1 & $\begin{array}{l}\text { Low: if there is no cooperation between } \\
\text { members based on group goals }\end{array}$ \\
\hline & Group meeting & 1) & Frequency of meetings in 6 months & 3 & High: $>3$ times \\
\hline & intensity & & & $\begin{array}{l}2 \\
1\end{array}$ & $\begin{array}{l}\text { Moderate: } 1-2 \text { times } \\
\text { Low: } 0\end{array}$ \\
\hline & & 2) & Meeting quality & & \\
\hline & & a) & $\begin{array}{l}\text { The suitability of the discussion material with } \\
\text { the needs of fish farmers }\end{array}$ & 3 & $\begin{array}{l}\text { High: always adapted to the needs of } \\
\text { members }\end{array}$ \\
\hline & & & & 2 & $\begin{array}{l}\text { Moderate: sometimes adapted to the } \\
\text { needs of members }\end{array}$ \\
\hline & & & & 1 & $\begin{array}{l}\text { Low: not adapted to the needs of } \\
\text { members }\end{array}$ \\
\hline & & b) & $\begin{array}{l}\text { Suitability of meeting times with members' free } \\
\text { time }\end{array}$ & 3 & $\begin{array}{l}\text { High: always adjusted to the members' } \\
\text { free time }\end{array}$ \\
\hline & & & & 2 & $\begin{array}{l}\text { Moderate: sometimes adjusted to } \\
\text { members' free time }\end{array}$ \\
\hline & & & & 1 & Low: not adjusted to members' free time \\
\hline \multirow[t]{18}{*}{2.} & \multicolumn{5}{|l|}{ Work factors of group } \\
\hline & $\begin{array}{l}\text { a. Member satisfying } \\
\text { function }\end{array}$ & 1) & The group's ability to satisfy members' needs & $\begin{array}{l}3 \\
2\end{array}$ & $\begin{array}{l}\text { High: if members' needs are met } \\
\text { Moderate: if only part of the members' } \\
\text { needs are met }\end{array}$ \\
\hline & & & & 1 & Low: if the needs of members are not met \\
\hline & & 2) & $\begin{array}{l}\text { The frequency of providing services to members } \\
\text { is related to the needs of members }\end{array}$ & 3 & $\begin{array}{l}\text { High: if there is and meet the needs of } \\
\text { members }\end{array}$ \\
\hline & & & & 2 & $\begin{array}{l}\text { Moderate: if there is but not sufficient for } \\
\text { members' needs }\end{array}$ \\
\hline & & & & 1 & Low: if not available \\
\hline & b. Coordination function & 1) & Gather members in group activities & 3 & High: if all gathered \\
\hline & & & & 2 & Moderate: if only partially \\
\hline & & & & 1 & Low: if there is no gathering \\
\hline & & 2) & Involve members in group activities & 3 & High: if all involved \\
\hline & & & & 2 & Moderate: if only partially \\
\hline & & & & 1 & Low: if no one is involved \\
\hline & c. Initiative function & 1) & $\begin{array}{l}\text { The group's ability to accommodate member } \\
\text { initiatives }\end{array}$ & 3 & $\begin{array}{l}\text { High: if all members have freedom of } \\
\text { opinion }\end{array}$ \\
\hline & & & & 2 & Moderate: if only partially \\
\hline & & & & 1 & Low: if not free opinion \\
\hline & & 2) & $\begin{array}{l}\text { The ability of the group to realize the initiative of } \\
\text { the members }\end{array}$ & $\begin{array}{l}3 \\
2\end{array}$ & $\begin{array}{l}\text { High: if all initiatives can be realized } \\
\text { Moderate: if some initiatives can be } \\
\text { realized }\end{array}$ \\
\hline & & & & 1 & Low: if there is no initiative can be realized \\
\hline & $\begin{array}{l}\text { d. Function invites } \\
\text { participation }\end{array}$ & 1) & $\begin{array}{l}\text { The group's ability to involve its members in } \\
\text { every activity }\end{array}$ & 3 & $\begin{array}{l}\text { High: if all members are involved in all } \\
\text { activities }\end{array}$ \\
\hline
\end{tabular}


e. Function explain

1) Members' knowledge of group decisions

2) Members' understanding of group decisions

3. External factors of group

a. Formal and informal leader support

1) Support group activities by:

a) Formal leader (village leader)

b) Non-formal leaders (community leaders)

b. Physical condition of group location

1) Ease of group location for members to visit

2) There is a physical building for group meetings

3) Convenience of meeting place

4. The effectiveness of the group

a. Productivity of the group

b. Group member satisfaction
1) Achievement of group goals in terms of meeting the needs of members' production facilities in the last 1 year

2) Achievement of targeted results in each group activity

1) Feeling proud of the group

2) Feelings of pride in the progress of group goals

3) Member satisfaction with the success of the freedom to participate in:

a) Activity planning

b) Implementation of activities

4) Member satisfaction with group rules
Moderate: if only part of the members are involved in each activity Low: if no members are involved in every activity

High: if all members know

Moderate: if only partially

Low: if none of the members know

High: if all members have understood Moderate: if only partially

Low: if none of the members have understood

High: if always supported

Moderate: if rarely supported

Low: if never supported

High: if always supported

Moderate: if rarely supported

Low: if never supported

High: if it's easy

Moderate: if it's easy enough

Low: if not easy

High: if available and permanent

Moderate: if available but not permanent

Low: if not available

High: if the meeting place has very complete infrastructure

Moderate: if the meeting place has

incomplete infrastructure

Low: if the meeting place does not have infrastructure

High: if the needs of members' production facilities are available and fulfilled Moderate: if the need for production facilities is available but only partially fulfilled

Low: if not fulfilled

High: always successful

Moderate: sometimes it works

Low: never worked

High: feel so proud

Moderate: quite proud

Low: not proud

High: if the group is progressing

Moderate: if the group is progressing somewhat

Low: if the group is not progressing

High: always involved in planning

Moderate: rarely involved in planning

Low: not involved in planning

High: always involved in group activities

Moderate: rarely involved in group

activities

Low: never involved in group activities

High: if the group rules are in accordance

with the wishes of the members

Moderate: if the group rules are quite in

accordance with the wishes of the

members

Low: if the group rules are not in

accordance with the wishes of the members 